다 I프 IU 소

Jurnal Gentiaras Manajemen dan Akuntasi

Laman Jurnal: jurnal.gentiaras.ac.id/index.php/Gema/index

ISSN : 2086-9592 (p) , 2721-5490 (e)

\title{
Penentuan Pengungkapan Sustainability Report dengan GRI Standar pada Sektor Non-Keuangan
}

\author{
Maria Aditya Setiani, Imelda Sinaga \\ Sekolah Tinggi Ilmu Ekonomi Gentiaras, Lampung
}

*email: proficiatmelsi@gmail.com

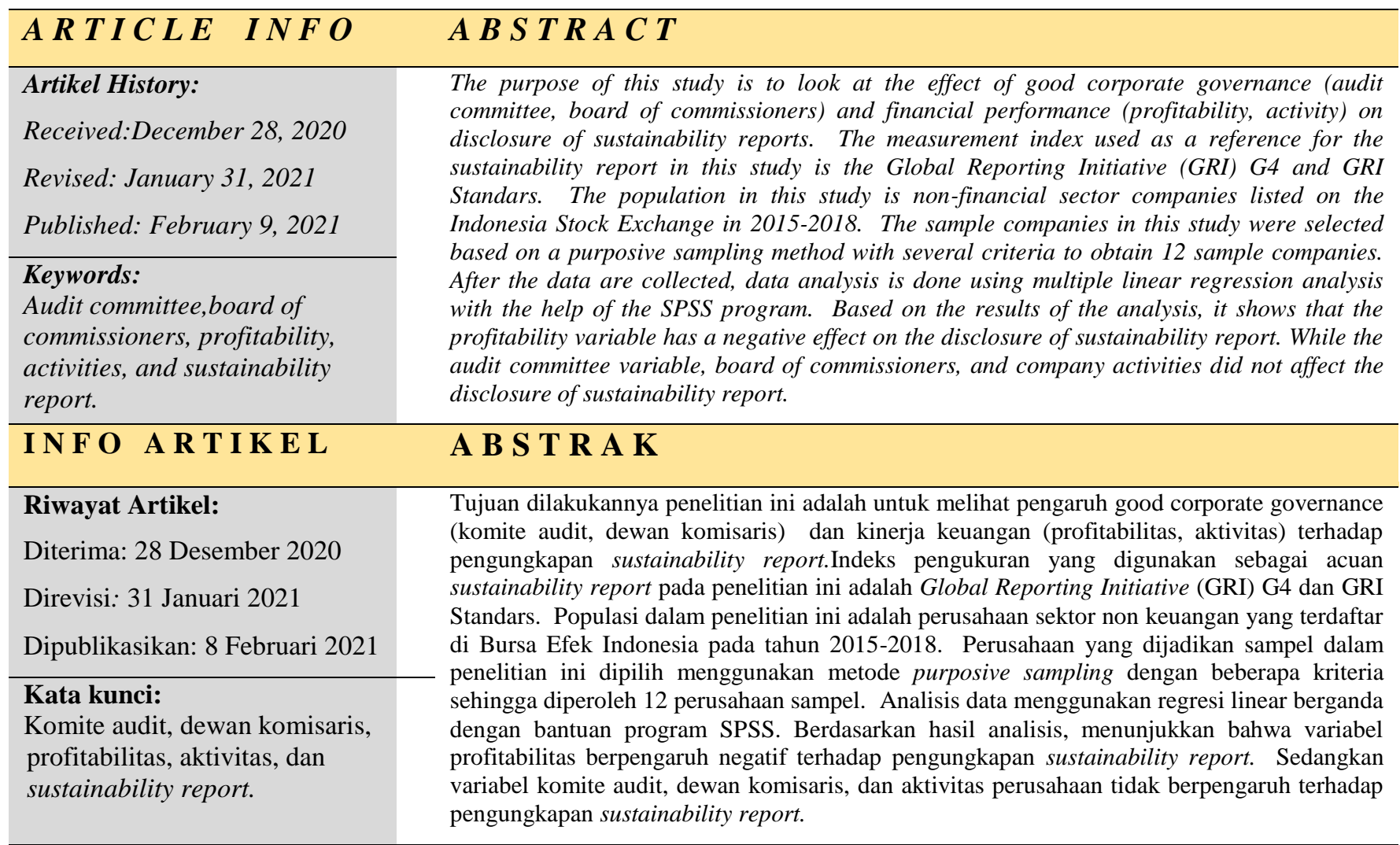




\section{PENDAHULUAN}

Sustainability report merupakan laporan keberlanjutan yang berisi tentang kinerja ekonomi, sosial, dan lingkungan perusahaan. Konsep pembangunan berkelanjutan ini merubah pandangan bagi para pelaku bisnis, dimana perusahaan tidak hanya fokus pada keuntungan/profit semata, tetapi berfokus pula pada kelestarian lingkungan dan kesejahteraan masyarakat sekitar yang sering dikaitkan dengan corporate social responsibility (CSR). Fenomena sustainability report di Indonesia adalah, sustainability report masih terbilang sepi peminat dimana banyak perusahaan yang belum mengungkapkan sustainability report tersebut. Menurut data dari GRI dan BEI per 23 April 2019, yang menunjukkan bahwa dari total 629 perusahaan yang tercatat, hanya sebanyak 110 laporan keberlanjutan yang telah dirilis oleh perusahaan. Hal ini jelas tergambar bahwa laporan keberlanjutan masih dianggap sebagai laporan yang belum menjadi kebutuhan primer bagi perusahaan.

Pengaruh pengungkapan sustainability report, diantaranya adalah good corporate governance (GCG) yang berfokus pada pihak manajemen yang memiliki kendali dan wewenang dalam setiap pengambilan kebijakan dan keputusan dalam suatu perusahaan, Artinya setiap informasi yang dikeluarkan dari perusahaan kepada publik merupakan hasil kebijakan dan keputusan dari pihak manajemen. Effendi (2016) menyebutkan bahwa, terdapat kecenderungan atau trend yang akan meningkatkan tuntutan publik atas transparansi dan akuntabilitas perusahaan yang merupakan wujud nyata dari Good Corporate Governance (GCG). Salah satu implementasi GCG di perusahaan adalah penerapan Corporate Social Responsibility (CSR), yang merupakan bagian penting dalam laporan keberlanjutan. Apabila perusahaan memiliki tata kelola yang baik atau kinerja manajemen yang baik, maka tingkat transparansi dan akuntabilitas perusahaan juga akan tinggi, salah satunya dengan upaya pengungkapan sustainability report tersebut. Adapun faktor lain berupa kinerja keuangan yang sering dikaitkan dengan profit atau keuntungan yang diperoleh dari kegiatan usaha suatu perusahaan. Menurut Widianto (2011), apabila perusahaan memiliki tingkat profitabilitas yang tinggi maka akan semakin besar pula tingkat pengungkapan informasi yang dilakukan oleh perusahaan tersebut, seperti sustainability report dan annual report yang secara potensial akan menarik minat investor. Dalam penelitian ini sektor non keuangan yang terdiri dari 12 perusahaan dipilih menjadi sampel penelitian karena perusahaan-perusahaan tersebut sebagian besar dinilai menimbulkan indikasi kerusakan lingkungan akibat kegiatan produksi perusahaan, sehingga penting untuk menerapkan ekonomi keberlanjutan. Dengan demikian penelitian ini dilakukan untuk mengetahui apakah faktor-faktor seperti Good Corporate Governance (GCG) dan 
kinerja keuangan dapat mempengaruhi perusahaan dalam melakukan pengungkapan sustainability report.

\section{METODE PENELITIAN}

\section{Desain Penelitian}

Jenis penelitian yang digunakan dalam penelitian ini adalah jenis penelitian kuantitatif. Metode penelitian kuantitatif merupakan metode penelitian yang digunakan untuk meneliti suatu populasi atau sampel yang telah ditentukan. Penelitian ini dilakukan di PT. Bursa Efek Indonesia melalui media internet dengan situs www.idx.co.id dan website resmi masing-masing perusahaan yang dijadikan sebagai sampel penelitian.

\section{Populasi dan Sampel}

Populasi yang digunakan dalam penelitian ini, merupakan perusahaan sektor non keuangan yang terdaftar di Bursa Efek Indonesia. Total seluruh perusahaan sektor non keuangan yang telah terdaftar di BEI per 15 Januari 2020 adalah 586 perusahaan, teknik pengambilan sampel yang digunakan adalah purposive sampling method dengan menetapkan ciri-ciri khusus, sehingga diperolehlah jumlah sampel yang kemudian akan diteliti pada perusahaan sektor non keuangan yang terdaftar di Bursa Efek Indonesia adalah sebanyak 12 perusahaan sampel dengan periode penelitian selama 4 tahun sehingga diperoleh data sebanyak 48 data.

\section{Definisi Operasional}

Penelitian ini menggunakan 4 variabel independen yaitu, komite audit, dewan komisaris, profitabilitas, dan aktivitas serta variabel dependen yakni pengungkapan sustainability report. Adapun indikator variabel yang digunakan, diantaranya: 1) Komite audit dihitung berdasarkan jumlah seluruh anggota komite audit dari perusahaan sampel menurut Barung et al $(2018)$; 2) Dewan komisaris dihitung berdasarkan jumlah seluruh anggota dewan komisaris dari perusahaan sampel menurut Restu et al (2017); 3) Profitabilitas dihitung menggunakan rumus profit margin dengan membagi laba bersih dan penjualan/pendapatan dari perusahaan sampel menurut Dailing (2018); 4) Aktivitas dihitung menggunakan rumus total asset turnover yang kemudian membagi dengan penjualan/pendapatan dan total asset dari perusahaan sampel. Fitri et al (2018); 5) Pengungkapan sustainability report dihitung menggunakan indikator standar Global Reporting Initiative (GRI). Dengan menggunakan standar GRI-G4 pada tahun 2015-2016 dengan indikator 91 item pengungkapan, dan GRI STANDARS pada tahun 2017-2018 dengan indikator 77 item pengungkapan. Kemudian jumlah dari masing-masing pengungkapan sustainability report 
perusahaan sampel dibagi dengan indeks atau indikator berdasarkan standar yang digunakan menurut Zakiyah (2016).

\section{Teknik Pengumpulan Data}

Jenis data dalam penelitian ini adalah menggunakan data sekunder yaitu data laporan keuangan dan laporan CSR melalui website resmi BEI yakni www.idx.co.id dan website resmi perusahaan.

\section{Teknik Analisis Data}

Dalam penelitian ini teknik analisis data yang digunakan adalah statistik deskriptif dan regresi linier berganda, yang terdiri atas beberapa tahapan sebagai berikut, (Ghozali, 2011):

1. Analisis Statistik Deskriptif, statistik deskriptif adalah pengolahan data untuk mendeskripsikan atau memberikan gambaran terhadap objek yang akan diteliti,melalui data sampel atau populasi.

2. Uji Asumsi Klasik, merupakan pengujian yang harus dilalui oleh model regresi atau data yang digunakan agar layak mejadi sampel data dalam penelitian, yang terdiri dari uji Normalitas, uji Multikolinearitas, uji Heteroskedastisitas, dan uji Autokorelasi.

3. Analisis Regresi Linier Berganda dan Uji Hipotesis. Pada penelitian ini menggunakan uji Signifikansi Parameter Individual (Uji Statistik t), uji Statistik F, dan uji Ketepatan Perkiraan Model $\left(\mathrm{R}^{2}\right)$.

\section{HASIL DAN PEMBAHASAN}

Analisis data dilakukan dengan menggunakan metode analisis regresi linier berganda, dan sebelumnya dilakukan uji statistik deskriptif dan pengujian asumsi klasik untuk melihat gambaran data dan kelayakan model regresi yang digunakan dalam penelitian ini. Setelah itu dilakukan pengujian hipotesis untuk menghasilkan jawaban atas hipotesis yang diajukan.

\section{Analisis Statistik Deskriptif}

Tabel 1. Hasil Statistik Deskriptif

\begin{tabular}{lrllll}
\hline & \multicolumn{1}{c}{$\mathbf{N}$} & \multicolumn{1}{r}{ Min } & Max & Mean & \multicolumn{1}{c}{ Std. Deviation } \\
\hline Pengungkapan & 48 & 0,0769 & 0,9481 & 0,307471 & 0,178818 \\
Sustainability Report & & & & & \\
Komite Audit & 48 & 2 & 6 & 3,52 & 0,772 \\
Dewan Komisaris & 48 & 3 & 11 & 6,35 & 1,792 \\
Profitabilitas & 48 & $-0,1368$ & 0,2519 & 0,061917 & 0,686744 \\
Aktivitas & 48 & 0,2625 & 1,3916 & 0,623058 & 0,301890 \\
\hline
\end{tabular}


Tabel 1 menampilkan beberapa data yang dapat diartikan bahwa

1) Pengungkapan Sustainability Report

Selama 4 tahun periode penelitian, pengungkapan sustainability report pada perusahaan sampel paling rendah berdasarkan nilai minimum sebesar 0,07969 atau $7,69 \%$ pengungkapan, dan paling tinggi sebesar 0,9481 atau 94,81\% pengungkapan dengan rata-rata pengungkapan sebesar 0,3074 atau $30,17 \%$.

2) Komite Audit

Berdasarkan tabel di atas, perusahaan sampel memiliki paling banyak 6 anggota dan paling sedikit 2 anggota komite audit, dan jika rata-rata sebesar 3,52 artinya jumlah anggota komite audit dalam perusahaan sampel memiliki paling tidak 3 sampai 4 orang anggota.

3) Dewan Komisaris

Berdasarkan tabel di atas, perusahaan sampel memiliki paling banyak 11 anggota dan paling sedikit 3 anggota dewan komisaris, dan jika rata-rata sebesar 6,35 artinya jumlah anggota dewan komisaris dalam perusahaan sampel memiliki paling tidak 6 sampai 7 orang anggota.

4) Profitabilitas

Perusahaan sampel memiliki nilai minimum sebesar-0,1368 atau $-13,68 \%$ yang menandakan selama periode tahu penelitian, perusahaan sampel pernah mengalami kerugian sebesar $-13,68 \%$. Sedangkan nilai maksimum sebesar 0,2519 atau $25,19 \%$ yang artinya mengalami keuntungan paling tinggi sebesar 25,19\%. Jika dirata-rata rasio keuntungan adalah sebesar 0,0619 atau 6,19\%.

5) Aktivitas 
Pada tabel nilai minimum sebesar 0,2625 artinya selama tahun penelitian, perusahaan sampel memiliki perputaran total aktiva paling sedikit ada sebanyak 0,2625 kali perputaran, dengan perputaran total aktiva tertinggi adalah 1,3916 kali perputaran.

\section{Uji Asumsi Klasik}

1) Uji Normalitas

Tabel 2. Hasil Uji Kolmogorov Smirnov(KS)

\begin{tabular}{lll}
\hline & & $\begin{array}{c}\text { Unstandardiz } \\
\text { Od Residual }\end{array}$ \\
\hline $\mathrm{N}$ & & 48 \\
\hline Normal Paramotor $^{\mathrm{a}, \mathrm{b}}$ & Mean & 0,0000000 \\
& Std. & 0,16290918 \\
& $\begin{array}{l}\text { Deviation } \\
\text { Absolute }\end{array}$ & 0,166 \\
& Positive & 0,166 \\
& Negative & $-0,105$ \\
\hline Kolmogorov Smirnov & & 1,152 \\
(KS) & & \\
\hline Asymp. Sig. (2-tailed) & & 0,141 \\
\hline
\end{tabular}

Dari tabel 2 diatas, nilai Asymp. Sig. (2-tailed) adalah 0,141 dimana nilai tersebut lebih besar dari 0,05 sehingga disimpulkan bahwa data dalam penelitian memiliki distribusi yang normal dan dapat dilakukan tahap selanjutnya.

2) Uji Multikolinearitas

Tabel 3. Hasil Uji Multikolinearitas

\begin{tabular}{|l|c|c|}
\hline \multirow{2}{*}{\multicolumn{1}{|c|}{ Model }} & \multicolumn{2}{c|}{ Collinearity Statistic s } \\
\cline { 2 - 3 } & Tolerance & VIF \\
\hline Komite Audit & 0,974 & 1,027 \\
\hline Dewan Komisaris & 0,759 & 1,317 \\
\hline Profitabilitas & 0,935 & 1,070 \\
\hline Aktivitas & 0,719 & 1,391 \\
\hline
\end{tabular}

Dari tabel 3. di atas, dapat dilihat bahwa nilai tolerance lebih besar 0,10 dan nilai Variance Inflation Factor (VIF) lebih kecil dari 10, maka dapat disimpulkan bahwa model regresi yang dipakai dalam penelitian ini tidak terjadi multikolinearitas dan layak untuk digunakan. 
3) Uji Heteroskedastisitas

Tabel 4. Hasil Uji Glejser

\begin{tabular}{lcc}
\hline \multicolumn{1}{c}{ Model } & T & \multicolumn{1}{c}{ Sig } \\
\hline (Constant) & 0,687 & 0,496 \\
Komite Audit & 0,646 & 0,522 \\
Dewan Komisaris & 0,105 & 0,917 \\
Profitabilitas & 0,246 & 0,807 \\
Aktivitas & $-1,037$ & 0,306 \\
\hline
\end{tabular}

Berdasarkan tabel 4 di atas, dapat dilihat bahawa semua variabel memiliki nilia sig $>0,05$ sehingga dapat disimpulakan bahwa model regresi tidak terjadi gejala heteroskedastisitas.

4) Uji Autokorelasi

Tabel 5. Hasil Uji Autokorelasi

\begin{tabular}{cccccc}
\hline Model & R & R Square & $\begin{array}{c}\text { Adjusted R } \\
\text { Square }\end{array}$ & $\begin{array}{c}\text { Std. Error of the } \\
\text { Estimate }\end{array}$ & $\begin{array}{c}\text { Durbin- } \\
\text { Watson }\end{array}$ \\
\hline 1 & $0,412^{\mathrm{a}}$ & 0,170 & 0,093 & 0,1703179 & 1,915 \\
\hline \multicolumn{7}{c}{} \\
\hline $\mathbf{N}$ & $\mathbf{D}$ & DL & Tabel 6. Ringkasan Hasil Uji Autokorelasi \\
\hline 48 & 1,915 & 1,361 & 1,720 & 4-DL & 4-DU \\
\hline
\end{tabular}

Berdasarkan hasil uji autokorelasi pada tabel 5 dan 6 di atas, menunjukan bahwa nilai DU < D $<4$-DU atau 1,720 < 1,915 <2,280. Nilai Durbin Watson sebesar 1,915 berada diantara 1,720 sampai 2,280. Dengan demikian, disimpulkan bahwa data yang digunakan beresidual random, atau tidak terjadi gejala autokorelasi antar nilai residual.

\section{Analisis Regresi Linier Berganda}

Tabel 7. Hasil Uji Regresi Linear Berganda

\begin{tabular}{lrrr}
\hline \multirow{1}{*}{ Model } & \multicolumn{1}{c}{$\begin{array}{c}\text { Unstandardized } \\
\text { Coefficients }\end{array}$} & T & Sig \\
\cline { 2 - 2 } \multicolumn{1}{c}{ B } & & \\
\hline (Constant) & 0,595 & 3,159 & 0,003 \\
Komite Audit & $-0,019$ & $-0,589$ & 0,559 \\
Dewan Komisaris & $-0,019$ & $-1,197$ & 0,238 \\
Profitabilitas & $-0,987$ & $-2,639$ & 0,012 \\
Aktivitas & $-0,061$ & $-0,627$ & 0,534 \\
\hline
\end{tabular}

Berdasarkan hasil uji regresi linear berganda yang telah dilakukan pada tabel 7 diatas, diperoleh bahwa koefisien komite audit (X1) sebesar -0,019, dewan komisaris (X2) sebesar -0,019, 
profit margin (X3) sebesar $-0,987$, dan total asset turnover (X4) sebesar -0,061 sehingga diperoleh persamaan pada regresi berganda adalah sebagai berikut :

$$
\text { SRDI }=0,595-0,019 K A-0,019 D K-0,987 P M-0,061 T A T+e
$$

Berdasarkan persamaan hasil uji regresi linear berganda diatas menunjukkan bahwa :

a. Nilai konstanta (constant) menunjukkan nilai sebesar 0,595. Nilai ini menunjukkan bahwa, jika variabel-variabel independen dalam penelitian ini bernilai 0 , maka nilai pengungkapan sustainability reportnya adalah sebesar 0,595.

b. Nilai variabel komite audit adalah sebesar - 0,019 yang artinya jika nilai variabel independen lainnya bersifat konstan, maka setiap kenaikan 1 satuan komite audit yang kemudian diikuti dengan pengungkapan sustainability report yang mengalami penurunan sebesar 0,019 .

c. Nilai variabel dewan komisaris sebesar - 0,019 artinya jika nilai variabel independen lainnya bersifat konstan, maka setiap kenaikan 1 satuan dewan komisaris yang kemudian pengungkapan sustainability report akan diikuti dengan penurunan sebesar 0,019.

d. Nilai variabel profitabilitas yang diukur menggunakan profit margin adalah sebesar 0,987 artinya jika nilai variabel independen lainnya bersifat konstan, maka setiap kenaikan 1 satuan profit margin akan diikuti dengan penurunan pengungkapan sustainability reportnya adalah sebesar $0,987$.

e. Nilai variabel aktivitas yang diukur menggunakan total asset turnover adalah sebesar0,061 artinya jika nilai variabel independen lainnya bersifat konstan, maka setiap kenaikan 1 satuan total asset turnover, yang kemudian pengungkapan sustainability report akan diikuti dengan penurunan sebesar 0,061 . 


\section{Uji Hipotesis}

1) Uji Signifikansi Parameter Individual (Uji Statistik t)

\begin{tabular}{lrr}
\multicolumn{3}{c}{ Tabel 8. Hasil Uji Statistik t } \\
\hline \multicolumn{1}{c}{ Model } & T & Sig \\
\multicolumn{1}{c}{$\mathbf{1}$} & & \\
\hline (Constant) & 3,159 & 0,003 \\
Komite Audit & $-0,589$ & 0,559 \\
Dewan Komisaris & $-1,197$ & 0,238 \\
Profitabilitas & $-2,639$ & 0,012 \\
Aktivitas & $-0,627$ & 0,534 \\
\hline
\end{tabular}

Berdasarkan hasil pengujian statistik t pada tabel 8 di atas dapat dijabarkan sebagai berikut :

a) Pengaruh komite audit (X1) terhadap pengungkapan sustainability report (Y).

Komite audit memiliki nilai signifikansi sebesar 0,559 , sehingga nilai sig $>0,05$ yang artinya komite audit tidak berpengaruh terhadap pengungkapan sustainability report sehingga Ha $\mathrm{H}_{1}$ ditolak. Hasil penelitian ini sama dengan penelitian Aliniar (2017) dan Barung (2018) menunjukkan bahwa jumlah anggota komite audit dalam suatu perusahaan tidak menentukan meningkatnya kualitas pengungkapan sustainability report, karena yang menjadi dasar dalam melakukan pengungkapan informasi perusahaan adalah, adanya prinsip keterbukaan/transparansi dan akuntabilitas dari perusahaan terhadap lingkungan dan stakeholders, sehingga bukan berdasarkan banyak atau sedikitnya anggota komite audit.

b) Pengaruh dewan komisaris (X2) terhadap pengungkapan sustainability report (Y).

Dewan komisaris berdasarkan hasil analisis memiliki nilai signifikansi sebesar 0,238, sehingga nilai sig > 0,05 sehingga dewan komisaris tidak berpengaruh terhadap pengungkapan sustainability report sehingga $\mathrm{Ha}_{2}$ ditolak. Hasil dari penelitian ini konsisten dengan penelitian Aliniar (2017) dan Barung (2018), yang menunjukkan bahwa besar kecilnya ukuran dewan komisaris tidak menentukan kualitas pengungkapan sustainibility report, karena yang menjadi dasar perusahaan dalam melakukan pengungkapan informasi adalah, adanya kesadaran dari perusahaan untuk menerapkan prinsip keterbukaan/transparansi dan akuntabilitas terhadap lingkungan dan stakeholders, hal ini dapat menunjukkan bahwa jumlah anggota dewan komisaris bukan menjadi dasar utama bagi perusahaan dalam melakukan pengungkapan informasi. 
c) Pengaruh profitabilitas perusahaan (X3) terhadap pengungkapan sustainability report (Y).

Variabel profitabilitas yang diukur menggunakan profit margin memiliki nilai signifikansi sebesar 0,012, sehingga nilai sig $<0,05$ dan nilai $t_{\text {hitung }}$ sebesar $-2,639$ sehingga profitabilitas memiliki pengaruh yang negatif terhadap pengungkapan sustainability report sehingga $\mathrm{Ha}_{3}$ ditolak, hasil penelitian ini konsisten dengan penelitian Yustia (2013). Hasil penelitian menunjukkan bahwa, hubungan antara profitabilitas dan tingkat pengungkapan sustainability report adalah, saat suatu perusahaan memiliki laba yang tinggi, perusahaan tidak perlu melaporkan hal-hal lainnya, selain suksesnya keuangan perusahaan tersebut. Sementara, saat tingkat profitabilitas suatu perusahaan tersebut rendah maka, perusahaan akan berupaya untuk memaksimalkan kinerja lain selain kinerja keuangan seperti, kinerja ekonomi, sosial, dan lingkungan perusahaan dengan mempublikasikannya lewat sustainability report, hal ini dapat menjadi upaya dan strategi perusahaan untuk meningkatkan dan mempertahankan citra baik disaat profit perusahaan rendah.

d) Pengaruh aktivitas perusahaan (X4) terhadap pengungkapan sustainability report $(\mathrm{Y})$.

Variabel aktivitas yang diukur menggunakan total asset turnover memiliki nilai signifikansi sebesar 0,534, sehingga nilai sig > 0,05 sehingga aktivitas tidak memilki pengaruh terhadap pengungkapan sustainability report, sehingga $\mathrm{Ha}_{4}$ ditolak hasil penelitian ini didukung dengan penelitian Lestari (2019). Hasil penelitian tersebut menunjukkan bahwa, aktivitas suatu perusahaan memiliki sifat yang lebih mengutamakan pada tindakan dalam pengelolaan aktiva dan sumber daya perusahaan untuk pencapaian dalam hal kinerja keuangan. Sehingga tidak ada kaitannya secara langsung dengan upaya perusahaan untuk mengungkapkan sustainability report, karena sustainability report merupakan laporan yang dijadikan perusahaan untuk meningkatkan kinerja lingkungan dan sosial perusahaan.

2) Uji Statistik F

Tabel 9. Hasil Uji Statistik F

\begin{tabular}{llllrc}
\hline \multicolumn{1}{r}{ Model } & \multicolumn{1}{c}{ Sum of Squares } & df & Mean Square & F & Sig. \\
\hline Regression & 0,256 & 4 & 0,064 & 2,202 & $0,085^{\text {a }}$ \\
Residual & 1,247 & 43 & 0,029 & & \\
Total & 1,503 & 47 & & & \\
\hline
\end{tabular}


Berdasarkan tabel 9 di atas, hasil uji statistik $\mathrm{F}$ menunjukkan bahwa nilai $\mathrm{F}_{\text {hitung }}$ sebesar 2,202 dengan taraf signifikansi sebesar 0,085. Dengan demikian nilai signifikansi F > 0,05 sehingga dapat disimpulkan bahwa variabel independen dalam model regresi ini yaitu, komite audit, dewan komisaris, profitabilitas, dan aktivitas secara bersama-sama tidak memiliki pengaruh terhadap pengungkapan sustainability report, sehingga hipotesis Ha5 dalam penelitian ini ditolak.

3) Uji Ketepatan Perkiraan Model $\left(\mathrm{R}^{2}\right)$

Tabel 10. Hasil Uji Ketepatan Perkiraan Model $\left(\mathrm{R}^{2}\right)$

\begin{tabular}{lcccc}
\hline Model & R & R Square & $\begin{array}{c}\text { Adjusted R } \\
\text { Square }\end{array}$ & Std. Error of the Estimate \\
\hline 1 & $0,412^{\mathrm{a}}$ & 0,170 & 0,093 & 0,1703179 \\
\hline
\end{tabular}

Berdasarkan tabel 10 di atas, dapat dilihat bahwa nilai Adjusted R-Square adalah 0,093 atau secara persentase sebesar 9,3\%. Hal ini menunjukkan bahwa pengaruh variabel independen terhadap variabel dependen yang dipakai dalam penelitian ini cenderung memilki pengaruh yang kecil dan selebihnya 90,7\% dipengaruhi oleh faktor lain diluar variabel penelitian yang digunakan.

\section{KESIMPULAN}

Komite audit tidak berpengaruh terhadap pengungkapan sustainability report sehingga $\mathrm{Ha}_{1}$ ditolak. Hasil penelitian ini menunjukkan bahwa banyaknya jumlah anggota komite audit tidak menentukan meningkatnya kualitas pengungkapan sustainability report, karena yang menjadi dasar dalam melakukan pengungkapan informasi perusahaan adalah, adanya prinsip keterbukaan/transparansi dan akuntabilitas dari perusahaan terhadap lingkungan dan stakeholders, sehingga bukan berdasarkan banyak atau sedikitnya anggota komite audit.

Dewan komisaris tidak berpengaruh terhadap pengungkapan sustainability report sehingga $\mathrm{Ha}_{2}$ ditolak. Hasil penelitian ini menunjukkan bahwa besar kecilnya proporsi dewan komisaris tidak menentukan kualitas pengungkapan sustainibility report yang dihasilkan oleh perusahaan, karena yang menjadi dasar perusahaan dalam melakukan pengungkapan informasi adalah, adanya kesadaran dari perusahaan untuk menerapkan prinsip keterbukaan/transparansi dan akuntabilitas terhadap lingkungan dan stakeholders, hal ini menunjukkan bahwa banyaknya jumlah anggota dewan komisaris dalam suatu perusahaan, bukan menjadi dasar utama bagi perusahaan dalam melakukan pengungkapan informasi. 
Profitabilitas berpengaruh negatif terhadap pengungkapan sustainability report sehingga $\mathrm{Ha}_{3}$ ditolak. Hasil penelitian ini menunjukkan bahwa, profitabilitas dan tingkat pengungkapan sustainability report memiliki hubungan saat perusahaan memiliki laba/keuntungan yang tinggi, perusahaan tidak perlu melaporkan hal-hal lain, selain kesuksesan keuangan perusahaan. Sementara, pada saat tingkat profitabilitas perusahaan rendah maka, perusahaan akan berupaya untuk memaksimalkan kinerja lain selain kinerja keuangan seperti, kinerja ekonomi, sosial, dan lingkungan suatu perusahaan dengan mempublikasikannya lewat sustainability report, hal ini dapat menjadi upaya dan strategi perusahaan untuk meningkatkan dan mempertahankan citra baik disaat profit perusahaan rendah.

Aktivitas tidak berpengaruh terhadap pengungkapan sustainability report, sehingga $\mathrm{Ha}_{4}$ ditolak. Hasil dari penelitian ini menunjukkan bahwa, aktivitas suatu perusahaan memiliki sifat yang lebih mengutamakan pada tindakan dalam pengelolaan aktiva dan sumber daya perusahaan untuk pencapaian dalam hal kinerja keuangan. Sehingga tidak ada kaitannya secara langsung dengan upaya perusahaan untuk mengungkapkan sustainability report, karena sustainability report merupakan laporan yang dijadikan oleh suatu perusahaan untuk meningkatkan kinerja lingkungan dan sosial perusahaan.

Komite audit, dewan komisaris, profitabilitas, dan aktivitas secara simultan atau bersamasama tidak memiliki pengaruh terhadap pengungkapan sustainability report, sehingga Ha $\mathrm{d}_{5}$ ditolak. Hal tersebut menunjukkan bahwa proporsi komite audit dan dewan komisaris serta kinerja keuangan secara bersama-sama, tidak sepenuhnya memberikan pengaruh terhadap pengungkapan sustainability report.

Saran yang dapat penulis berikan dalam penelitian ini adalah bagi perusahaan Hendaknya pihak manajemen dalam suatu perusahaan dapat meningkatkan pengungkapan sustainability report lewat penerapan prinsip Good Corporate Governance (GCG); bagi pemerintahan Pengungkapan sustainability report di Indonesia belum banyak dilakukan oleh perusahaan, padahal pengungkapan sustainability report sudah diatur dalam POJK No. 51/POJK.3/2017 tetang penerapan keuangan berkelanjutan, namun pada pelaksanannya masih banyak perusahaan di Indonesia yang belum menerapkan. Oleh karena itu pemerintah diharapkan dapat membentuk perundang-undangan yang lebih tegas terkait penerapan sustainability report. Peluang penelitian selanjutnya dapat melakukan penelitian terhadap seluruh perusahaan, baik perusahaan sektor keuangan maupun sector non keuangan, dan menggunakan variabel lain yang dapat kemungkinan besar memiliki pengaruh 
terhadap pengungkapan sustainability report seperti menggunakan semua jenis rasio dan factorfaktor lain terkait dengan GCG.

\section{DAFTAR PUSTAKA}

Aliniar, Dwita. 2017. "Pengaruh Mekanisme Good Corporate Governance (Gcg) Dan Ukuran Perusahaan Terhadap Kualitas Pengungkapan Sustainability Report Pada Perusahaan Terdaftar Di Bei”. KOMPARTEMEN. Vol. 15, No.1.

Barung, Margaretha. dkk. 2018. "Pengaruh Mekanisme Good Corporate Governance Dan Ukuran Perusahaan Terhadap Kualitas Pengungkapan Sustainability Report (Studi Empiris Pada Seluruh Perusahaan Yang Listing Di Bursa Efek Indonesia Periode 2011-2016)". Jurnal Akuntansi \& Keuangan Daerah. Vol. 13, No. 2:76-89.

Dilling, F.A. 2010. "Sustainability reporting: what are the characteristics of corporations that provide high quality sustainability reports". International Business \& Economics Research Journal. Vol.9, No. 1.

Effendi, Arif. 2016. The Power of Good Corporate GovernanceTeori dan Implementasi. Edisi 2. Jakarta: Salemba Empat.

Fahmi, Irham. 2011. Analisa Laporan Keuangan. Bandung: Alfabeta.

Ghozali, Imam. 2011. Aplikasi Analisis Multivariate Dengan Program SPSS. Semarang: Badan Penerbit Universitas Diponegoro.

Ghozali, Imam. 2013. Aplikasi AnalisisMultivariate dengan Program IBM SPSS 21Update $\quad$ PLS Regresi. Semarang: Badan Penerbit Universitas Diponegoro.

Lestari, Nanda Ayu. 2019. Pengaruh Aktivitas Perusahaan, Corporate Governance dan Indonesia Sustainability Reporting Award (ISRA) Terhadap Pengungkapan Sustainability Report Perusahaan Yang Masuk dalam Indeks Saham Syariah Indonesia. Skripsi. Universitas Negeri Sunan Kalijaga Yogyakarta.

Widianto, Hari Suryono. 2011. Pengaruh Profitabilitas, Likuiditas, Leverage, Aktivitas, Ukuran Perusahaan, Dan Corporate Governance Terhadap Praktik Pengungkapan Sustainability Report. Skripsi. Universitas Diponegoro.

Yustia, Mega. 2013. "Pengaruh Kinerja Keuangan, Ukuran Perusahaan dan Corporate Governance Terhadap Pengungkapan Sustainability Report”. Diponegoro Journal of Accounting. Vol. 2, No. 3:1-10.

Zakiyah, Rizky. 2016. Pengaruh Good Corporate Governance (GCG), SIZE, dan Kinerja Keuangan Perusahaan terhadap Pengungkapan Sustainability Report (Global Report Initative G4 2013) (Studi Empiris pada perusahaan yang di Listed di Bursa Efek Indonesia (BEI) periode 2010-2014). Skripsi. Universitas Lampung. 